The Impact of Park Views on Property Values.

\author{
By \\ John L. Crompton \\ Department of Recreation, Park and Tourism Sciences \\ Texas A\&M University \\ And \\ Sarah Nicholls \\ Department of Business \\ Swansea University, Wales
}

August 2019

Submitted exclusively for publication consideration to Leisure Sciences 


\begin{abstract}
Twenty-seven empirical studies were identified that empirically estimated the impact on property values of views of open space. The review differentiated between street level and highrise building views. Among the 17 street-level view studies, only five found substantial premiums which ranged from $4.9 \%$ to $9.29 \%$, while four others reported either a small increase in value or mixed results. Five studies reported low-elevation views had no impact. Three reported a negative premium which was antithetical to expectations. In all three cases the view was of forest land, not parks or open space. Only ten studies addressed the impact of views from elevated buildings and nine of them were undertaken in China. The highest premiums were for views of residential gardens which two studies estimated at $24 \%$ and $17.2 \%$. Five studies reported view premiums for neighborhood parks averaging 5.6\%, while two studies counter-intuitively reported that mountain views had a negative premium.
\end{abstract}

Key words: property values, open space, views, parks. 


\section{The Impact of Park Views on Property Values.}

It has long been recognized that many people are willing to pay more for property located close to parks and open space, than for a residence that does not offer this amenity. This process of 'capitalization' of park land into increased property values has been termed "the proximate principle" (Crompton, 2004). Traditionally, proximity was defined in terms of distance and access. This was the definition used in a recent review of 33 empirical studies and concluded that while value premiums varied widely according to local contexts, "A premium of 8\%-10\% on properties adjacent to a passive park is a reasonable point of departure" (Crompton \& Nicholls, 2019, p.1). However, the authors of that review recognized the impact of proximity should be measured not only by distance and accessibility, but also by incorporating the impact on premiums of views.

It is widely acknowledged that views of iconic parks or waterfronts attract large premiums. For example, anecdotal estimates for apartments with a view of New York City's Central Park compared to those in the same properties without this view have ranged from $25 \%$ (Biggs, 2019) to 40\% (Ventiera, 2017), while offices with a view of Central Park often command premiums of over $100 \%$ (Wilson, 2007). Thus, a $95^{\text {th }}$ floor condominium recently sold for $\$ 30.7$ million ( $\$ 7,592$ per square foot), while a unit about half way down the same building sold for $\$ 4,216$ per square foot (Hang, 2019). The price of apartments or offices with these iconic views reflect not only the view per se, but also status, "showing off what you have and who you are" (Ventiera, 2017, p.3).

The high view premium, has led to developers 'gaming' New York City's complex zoning laws. These allow floors reserved for structural and mechanical equipment, no matter how much, not to count against the maximum height allowed in a zone. Consequently, developers needlessly create floors ostensibly for that purpose, because it enables them to make buildings far higher than would otherwise be permitted to capture the high view premium (Hang, 2019).

The investment of $\$ 490$ million into an ugly site in Chicago comprised of a rail yard, parking lot and small strip of open space, transformed it into Millennium Park which opened in 2004. It quickly became known as "the soul of Chicago" and attained iconic status. An analysis of the sales of condominiums in two proximate buildings compared prices of those with views of the Park with units that had no such views. The results of sales at the 400 East Randolph building are 
shown in Table 1. The analysis showed a premium for south-facing park views compared to northfacing lake and city views. There were not enough transactions to make a floor-to-floor comparison, so some of the premium may be attributable to units being on different floors. After 2005 , a $40 \%$ premium price per square foot, an average of $\$ 126$ per square foot, was consistently paid for a Millennium Park view (Texas A\&M University and DePaul University, 2011).

\section{Insert Table 1}

The Legacy at Millennium Park was a new condominium development. Additional sales data enabled a floor-to-floor comparison which eliminated the influence of floor height. Units with partial Millennium Park views were eliminated from the sample. On floors that had transactions for both views $(n=88)$ and non-views $(n=37)$ of the park, the average premium was $\$ 131$ per square foot, a 29\% premium (Texas A\&M University and DePaul University, 2011).

Because these iconic contexts tend to receive a high level of visibility, it is likely that the accessibility heuristic results in them being viewed as 'typical' (Kahneman, 2011). However, they are atypical of most people's housing options and atypical of premiums that 'ordinary' views command. Hence, they were excluded from this review. Two other parameters also narrowed the review's scope. First, views of water have been synthesized elsewhere and so were excluded (Nicholls \& Crompton, 2017, 2018). Also excluded because they are exceptional were views from property in tourism areas where the main attraction is the scenery. In these areas, when tax appraisers include views the premiums can be dramatic. For example, at a contentious town meeting in Orford, New Hampshire, a town of 1,040 that overlooks the Connecticut River and has views of neighboring Vermont and the White Mountains of New Hampshire, a property owner protested that the appraiser's inclusion of the view added $\$ 140,000$ to his property's underlying value of $\$ 22,900$, increasing his annual property taxes from $\$ 500$ to $\$ 3,000$. He argued that he could not control people's perception of the view and could not enjoy it himself since he was legally blind! (Webster, 2005).

Twenty-seven empirical studies were identified from a comprehensive search of the land economics, resource economics, landscape architecture and urban planning literatures. 'Snowball' searches extended this reach by using the references from those studies to identify 
those in other fields. The review differentiates between views from street level and those from high-rise buildings. A summary is given in Table 2.

Insert Table 2

\section{Street-Level View Studies.}

The earliest paper to address the impact of view on price was done in Nottingham, England, and appeared in 1974. It found that view did not result in a price premium (Davis, 1974). A pioneering study in the U.S. in Boulder, Colorado, reached a similar conclusion. The authors measured the impact of a view of a valley classifying each property as having: Excellent view, moderate view, or no view. Like the Nottingham study, none of the view categories were statistically significant. The authors attributed this to the small sample size, the difficulty of defining views, and periodic exposure to severe wind conditions (Correll, Lillydahl \& Singell, 1978).

In contrast, four other early U.S. studies reported view premiums. Morton (1977) in an Orange County, California, analysis used a dummy variable for "view lot" and showed it to be highly significant. The type of view was not specified (water, park, mountain, etc.) but the estimated premium was $\$ 19,700$ (means of variables were not given so the percentage premium could not be estimated). In nearby Los Angeles, a 1981 study similarly included a dummy variable for view lots. The type and quality of the views they represented were not described, but the author concluded the premium for a home on a view lot was 9.2\% compared to a non-view home (Gillard, 1981).

In the Boston metropolitan area, Li and Brown, (1980) ranked the views of the 781 sample properties from 1 (low) to 5 (high). A house with the highest ranking commanded a premium of 8.4\% compared to a house with the lowest score (Li \& Brown, 1980). In Fairfax County, Virginia, houses were classified according to whether or not they provided "a good view" but, again, the criteria used to define a good view were not specified. Rather, it was vaguely defined as "something that a typical buyer is likely to find appealing" (p. 601). The results suggested that a good view added about $8 \%$ to the value on a house (Rodriguez \& Sirmans, 1994). 
Results from these early studies were compromised because several of them had very small sample sizes, and all of them classified properties dichotomously into "view" and "no view" which was overly-simplistic since all views are not uniform. Rather, they vary by type (mountains, parks, ocean, or whatever) and by quality (full view, partial view etc.). This was demonstrated in a 1998 study in Bellingham, Washington, that primarily focused on water views, but included 50 properties in its sample of 5,095 which had an uninterrupted view of snow-covered mountains. The mountain views had a positive coefficient, but they were not significant (Benson, Hansen $\&$ Schwartz, 1998). In contrast, they reported an average view of the ocean added $25.6 \%$ to house price The lack of a premium for mountain views was relatively consistent with a 1985 study in neighboring Seattle which reported a view of the Cascade Mountains had a significant but very small impact (Casel \& Mendelsohn, 1985).

The emergence of digital elevation models which can be used with GIS to develop three dimensional landscapes facilitated the ability to do large scale studies of the effects of street-level views on house prices. A counter-intuitive outcome reported by three studies that measured views of forests or woodlands was that they had a negative impact on house price. This first emerged in an early study in England where a significant tract of woodland within I kilometer had a positive effect raising house prices by $7 \%$, but its presence as a significant element of a view had a negative effect on house price (Gerrod \& Willis, 1992).

A similar finding was reported in an analysis of two Connecticut communities located in the Farmington River Valley. The authors investigated the extent to which visibility influenced the proximate effect of various land cover on the price of single family residences. The cover variable was the percentage of land occupied by residential and commercial development, agriculture, forest, and surface water within 1-kilometer. The view variables were the percentage of land visible overall within 1 kilometer and the percentage of land visible in each land use/cover in the same radius (Patterson and Boyle, 2002). The authors' visibility measures were based exclusively on the spatial extent of land uses within the visible area. There was no allowance for distance; no height values allocated to buildings or other landscape features that could impede the view; and no recognition that the vertical buildings could contribute, rather than be only an obstruction, to a view.

The results indicated that development only detracted from sales price when it was directly observable from a property. While amount of forest surrounding a property had a marginally 
significant positive effect, the extent of visible forest land was significantly negative. This suggested that while people enjoy the amenities associated with nearby forest lands, they preferred views that featured other types of covers. The authors speculated: "As the percentage of visible forest increases, the property may seem more confined or closed-in...and the type of species and density of the forest may play a role" (p.422). They noted that exclusion of visibility measures "may lead to incorrect conclusions regarding the significance and signs of other environmental variables in hedonic price equations" (p.424).

A third analysis measuring the impact of forests was a large-scale study of properties along the Meramac Greenway in southern St. Louis County, Missouri. Forest views had a negative effect on home prices, and grassy recreational lands had no statistically significant effect. Similar results emerged from the pooled model with both spatial and time effects (Walls et al., 2015). The authors suggested two explanations for the counter-intuitive finding that the greater the percentage of forest in a property viewshed, the lower the property price. First, they believed it could be attributed to the landscape's generally low elevation. In contrast, to farmland and grassy recreational lands, the relatively dense hardwood forests impeded extended views. Second, while forest land had increased over the 24-year period of their study, farmland and grassland had decreased, so the increased supply of forest land may have reduced its potential for creating a premium.

In Ramsey County, a suburban area of St. Paul, Minnesota, the viewshed of each property was designed to capture the best view from its top story windows. Increasing the proportion of a home's viewshed comprised of grass (including lawn, golf course, playing field and prairie patch) and/or water (including lakes and streams) had significant positive impacts on price (Sander \& Polasky, 2009). The marginal implicit price for increasing the percentage of a home's view accounted for by grass or water by $10 \%$ was $2.2 \%(\$ 5,517)$ and $2.9 \%(\$ 7,417)$, respectively (relative to the mean price of $\$ 255,955$ ).

\section{International Studies.}

In an international context a study in Finland reported views of forest yielded a premium of $4.9 \%$, which contrasted with the negative effects of forest views in the U.S. studies (Tyrvaman \& Miettinen, 2000). Another early millennium study in Castellón, Spain, reported that a view of a garden or park did not impact the prices of 810 residential dwellings (including both houses and flats) (Morancho, 2003). The method of ascertaining the existence of such a view was not 
explained, however, and it seems probable that the more complex viewshed-based methodologies employed in later years were not used in this case.

A study in Glasgow, Scotland, was perhaps the first to include viewscapes that included the interruption role of buildings. It measured views from eye-level (1.7 meters), at a $45^{\circ}$ angle, up to 500 meters. The land use variables included public parks, but none of the extensive number of variables in the study had an impact on house prices. The authors characterized this as "a disappointing result" ((Lake et al. 2000, p.539). However, it is important that studies reporting no effect are published. If this is not done, then publication bias will lead to misplaced generalizations (Scholey \& Harrrison, 2003; Peplow, 2014)

The urban/suburban fringe of Dijon, France, was described as comprising many villages and small towns isolated from their neighbors by broad expanses of farmland, woods, and forests. The urban city of Dijon was not included in the analyses. The viewshed was measured by simulating the view of an observer whose eyes were 1.8 meters above ground level. Buildings meant that the view was narrow. Most added value came from the view within 70 meters of the property, beyond 300 meters it had no impact: "Trees close to houses but out of sight contribute to the residential setting by providing amenities (peace and quiet, fresh air, etc.), but their hedonic

price is a third of that of trees in view. Unseen farmland is worth just one-fifth of the hedonic price of farmland in sight" (Cavailhes et al, 2009, p.587). Like the earlier Patterson and Boyle findings, if a house was exposed to being viewed by other houses, then its price was lowered.

Noosa National Park in southeast Queensland, Australia, is located in an urban setting. The park sits on a headland, bordered by homes, apartments and tourist lodging facilities on its other sides. Unimproved land values of 641 single family housing blocks served as the dependent variable; park-related variables. View of the park (no, poor partial, good partial, excellent partial, full unobstructed) was included in the hedonic analysis. A good partial view of the park had a significant and positive impact upon price and a full panoramic view provided the greatest impact. The other three grades of park view all had the same minimal impact, though no view resulted in a slightly lower value than a place with even a glimpse (Pearson, Tisdell \& Lisle, 2002).

\section{Elevated View Studies}

It is almost axiomatic to recognize that prices go up with an apartment's floor number, because apartments on higher floors have superior landscape views, are not as exposed to noise 
sources, and are further removed from pollution (Jim \& Chen, 2009). However, an analysis of condominium and co-op apartment sales in Manhattan reported that height premiums were more nuanced:

Second floor prices were 19\% higher than first floor apartments where prices were lowest. There was little change until a substantial increase for the sixth through ninth floors. This was attributed to views on these floors enabling owners to clear New York's ubiquitous six-story buildings, gaze over the trees in Central Park, or see far enough to admire the Hudson or East Rivers. The prices increased in small increments until the twentieth floor, after which they tended to level off since the views from higher floors were often not any different from those at the twentieth floor (Stozier, 2010).

A study in Geneva, Switzerland, appears to be the only non-Chinese study that has investigated the influence of an elevated view in non-iconic contexts (Baranzini \& Schaerer, 2009). It reported results of views at three different heights: Ground floor, mid-height, and attic reflecting a focus on apartments rather than houses. The data set comprised 12,932 observations of monthly rents. Seven land cover types were considered (measured by the number of visible hectares of trees/forests, agriculture, water, buildings, urban parks, transportation, and industry), and views of the famous Jet d'eau (water fountain) and ancient cathedral. The seven land cover types were also aggregated to form natural-view and built-view diversity indices (with urban parks falling in the latter category). In the model that considered views of the two aggregated categories of natural and built environment, the expected statistically significant coefficients emerged (positive for natural, negative for built). Thus, the larger the view of natural areas and the smaller the view of development, the larger were the rents. In a second model that incorporated specific land cover types, significant positive effects were observed for views of water, the Jet d'eau and the ancient cathedral, and significant negative effects for urban parks and industrial areas. The authors suggested that negative externalities of busy parks might explain their negative effect, though the typical use and other characteristics of the parks in the study area were not expanded upon.

All of the other elevated view studies used Chinese samples - most of them from Hong Kong. The earliest of them confirmed that not all green spaces are viewed positively. In Chinese societies, views of a cemetery often are viewed negatively because some perceive them as likely to induce bad luck. This conventional wisdom was empirically confirmed by Tse and Love (2000), 
who reported views of a cemetery resulted in a statistically negative premium on apartment values of about $4 \%$.

In contrast, a study that compared premiums associated with balconies in a large estate with those that overlooked a garden reported unusually large positive view premiums. An "ordinary apartment with a normal view and no balcony" was used as the base for comparison. The analysis revealed that the garden view apartments sold at a $24 \%$ higher price than the base apartment (Chau \& Wong, 2004).

Two studies by the same authors examined the influence of mountain views on price. The mountains located on the periphery of Hong Kong are comprised of woodland, shrubs and grassland vegetation, and cover $67 \%$ of the city's land area. It was expected that views of them would raise price. However, their first analysis revealed that a broad mountain view depressed apartment prices by $6.7 \%$, while a confined view was statistically insignificant. The authors struggled to suggest an explanation for this surprising finding tentatively concluding:

People in Hong Kong seem to relish an inward-looking perception of the environment and manifest the preference for a cloistered domestic existence. Long-term exposure to inordinately high-rise and high-density living, and the corollary of deprivation of daily contacts with nature, might have partly muffled people's innate desire to be in the company of nature, or have failed to kindle or rekindle such a desire (Jim \& Chen, 2009, p.232).

A study published the following year by the same authors using the same sample confirmed these negative mountain-view findings. Their new analyses revealed a distance proximity premium for neighborhood parks of $14.93 \%$, while a view of those parks resulted in an additional premium of $1.95 \%$., raising the total premium to $16.88 \%$. However, a mountain view again was shown to decrease the sale price, this time by $2 \%$ which amounted to US $\$ 10,200$. In this report, the authors' explanation for the aversion to a mountain view was that apartment blocks providing such views were likely to be sited on steep slopes which induced a fear of being subjected to landslides (Jim $\&$ Chen, 2010). These negative premiums for mountain views are consistent with the results of the Bellingham study discussed above.

In a variation on the previous Hong Kong studies, other researchers measured green space view premiums at different floor levels. On average, the premium was 5.94\% (compared to 6.03\% for sea views). When premiums for floors 1-10, 11-20, and >20 were examined the green view 
premium was prominent at all three levels but, surprisingly, the sea view premium had a negative impact on the prices of condominiums located above the twentieth floor (Hui, Zhong \& Yu, 2012).

Two studies in Guangzhou, the largest city in south China, were undertaken by the same researchers who were responsible for two of the Hong Kong analyses. They assessed the value of a green space view to purchasers of units in high-rise apartment blocks (based on 652 sales in 2003-2004 and 521 sales in 2004). Both analyses employed a dummy variable to represent a view. In the first case, a view was estimated to account for $7.1 \%$ of selling price (fourth in influence after apartment size, floor, and proximity to a water body) (Jim \& Chen, 2006) In the second case, a green view had the expected positive effect for the city as a whole $(+8.6 \%$, compared to $+8.2 \%$ for a water view), and in new town areas $(+23.1 \%$, compared to $+13.7 \%$ for a water view), but was unexpectedly insignificant when only old town areas were considered (a water view was significant, adding 7.3\%) (Jim \& Chen, 2007). This latter finding was surprising, since the lack of green space in the old town areas was expected to trigger a substantial premium for views of it. The authors concluded, "Homebuyers are unwilling to pay for limited views of tiny and scattered green pockets" (p.426). The data showed that when proximity was measured by distance to green space in the old town there was a premium. This suggested there was a willingness to pay for green spaces that they can actually use for recreation and amenity, but not for green views of small patches of green.

In Wuhan, Jiao \& Liu, (2010) reported a premium of \$10 per square meter for each higher floor. The study did not explicitly measure "view", but the authors attributed their findings to "The apartments at higher floors [having] a better and wider view, more sunshine and better ventilation...The view from lower flats is often dominated by other buildings" (p.54). Attributing the premium for higher floors to greenery was informed by the authors' parallel finding that proportion of proximate greenery provided a premium.

In Shenzhen views of public urban parks led to a $4.67 \%$ increase in housing price. A much greater premium of $17.2 \%$ was associated with views of residential gardens within developments. At least some of the substantial difference in premiums was attributed to the design of public urban parks often being basic, bland, and unimaginative, and receiving minimal maintenance because of limited municipal funding. In addition, the residential gardens were literally situated on home owners' doorsteps. The authors explained the relatively high residential gardens' premium by observing: "Unlike single-family houses that are prevalent in western cities, almost all urban 
households in China do not have private gardens...Residents' only visual or physical access to greenery is the communal garden and urban parks." (Chen \& Jim, 2010, p. 236).

\section{Discussion.}

The importance of views in valuing properties was recognized several decades ago by the Appraisal Institute which recommended that appraisers consider the view of a parcel of real estate when estimating property value. However, the Institute offered little guidance on how to arrive at a premium amount (Rodriguez \& Sirmans, 1994). As Hume (1757) pointed out over 250 years ago, what constitutes an attractive view is determined in the mind contemplating it; and each mind perceives it differently. When this is combined with the array of different types and definitions of view; different cities; different cultural values; different measures and methods of analysis; and small sample sizes; a wide range of findings is inevitable. Nevertheless, results from the 27 studies included in this review offered several useful insights.

Among the 17 street-level view studies, only five found substantial premiums which ranged from $4.9 \%$ to 9.29 percent (no percentage could be estimated for the Morton (1977) dollar value premium), while four others reported either a small increase in value $(<1 \%)$ or mixed results. Five studies found that low-elevation views had no impact, while three reported a negative premium. This latter finding was antithetical to expectations. In all three cases the view was of forest land, not parks or open space. The authors of those studies struggled to find an explanation for their findings, but others have suggested they may be attributed to trees impeding more attractive views (Walls et al., 2015) or blocking out day light in the winter months (Garrod \& Willis, 1992).

The review showed that premiums at street level were much smaller than the $8 \%-10 \%$ premiums associated with distance proximity to green spaces (Crompton \& Nicholls, 2019), and were inconsequential in most contexts. However, an additional insight relating to proximity that did not emerge in the distance measure was that proximity to other buildings only adversely affected a premium if the development was visible from a property.

Given the ubiquity of high rise buildings in cities, and the frequency of articles in the popular press which feature anecdotes relating to the value of views, there were surprisingly few scientific studies that analyzed the value of view premiums. Even more surprising was the absence of any such studies undertaken in the U.S. Of the ten studies that were found, nine were done in China. Given the likelihood of different cultural and urban design characteristics from western societies, it is probably unwise to suggest the insights may be generalizable to the U.S. However, a finding 
that was consistent with that reported in the review of distance proximity (Crompton $\&$ Nicholls, 2019) was that premiums differed across types of open space i.e. cemeteries, woodland, parks, gardens, mountains et al.

The highest premiums in the China studies were for views of residential gardens which Chau \& Wong (2004) estimated at $24 \%$ and Chen \& Jim (2010) 17.2\%. The authors attributed this to communal gardens being the only greenery to which many residents in densely populated Chinese cities were regularly exposed. Five studies reported view premiums for neighborhood parks averaging $5.6 \%$ (range $1.95 \%-8.6 \%$ ). Two studies counter-intuitively reported that mountain views had a negative premium for reasons that were not obvious to the studies' authors (Jim \& Chen, 2009, 2010).

All of the studies reviewed relied on hedonic analysis, which is a revealed measure of value using house purchase decisions to infer values of views. Bishop, Lange and Mahbubul, (2004) demonstrated that incorporating contingent valuation which is a stated preference measure of view into a hedonic analysis could provide additional insights. Using a small sample of graduate students, they demonstrated the potential for experimentally manipulating images of different types and/or amounts of green space and measuring differences in contingent willingness to pay for alternative scenarios. In their illustrative example, they used views of three levels of each of three different land covers: dominated by water; a large park from a high elevation with different amounts of office buildings in the pictures taken from the top of a high building; and the same park scenarios viewed from a lower level. This appears to offer a valuable way forward. It is adaptable to any context; lends itself to using representative, rather than convenience, samples; does not require expensive observational field work; and is a relatively inexpensive approach to identifying view premiums. 


\section{References}

Biggs, C. (2009). Rooms with a view (and how much you'll pay for them. New York Times, May 10

Baranzini, A. \& Schaerer, C. (2011). A sight for sore eyes: Assessing the value of view and land use in the housing market. Journal of Housing Economics, 20(2), pp. 191-199.

Benson, E.D., Hansen, J.L., Schwartz, A.L. \& Smersh, G.T. (1998). Pricing residential amenities: The value of a view. Journal of Real Estate Finance, 16(1), pp. 55-73

Bishop, I.D., Lange, E. \& Mahbubul, A.M. (2004). Estimation of the influence of view components on high-rise apartment pricing using a public survey and GIS modeling. Environment and Planning B: Planning and Design, 31(3), pp. 439-452.

Casel, E \& Mendelsohn, R. (1985). The choice of functional forms for hedonic price equations. Journal of Urban Economics, 18(2), pp. 135-142.

Cavailhès, J., Brossard, T., Foltête, J-C., Hilal, M., Joly, D., Tourneux, F-P., Tritz, C. \& Wavresky, P. (2009). GIS-based hedonic pricing of landscape. Environmental Resource Economics, 44, pp. 571-590.

Chau, K.W. \& Wong, S.K. (2004). The value of the provision of a balcony in apartments in Hong Kong. Property Management 22(3), pp. 250-264.

Chen, W.Y. \& Jim, C.Y. (2010). Amenities and disamenities: A hedonic analysis of the heterogeneous urban landscape in Shenzhen (China), The Geographical Journal, 176(3), pp. 227-240.

Correll, M.R., Lillydahl, J.H., \& Singell, L.D. (1978). The effects of greenbelts on residential property values: Some findings on the political economy of open space. Land Economic, 54(2), pp. 207217.

Crompton, J.L. (2004). The proximate principle: The impact of parks, open spaces and water features on residential property values and the property tax base. Ashburn, VA: National Recreation and Park Association.

Crompton, J.L. \& Nicholls, S. (2019). The Impact on Property Values of Distance to Parks and Open Spaces: An Update of US Studies in the New Millennium. Journal of Leisure Research,

Davies, G. (1974). An econometric analysis of residential amenity. Urban Studies, 11(2), pp. 217-225.

Garrod, G.D. \& Willis, K.G. (1992). The environmental economic impact of woodland: A two-stage hedonic price model of the amenity value of forestry in Britain. Applied Economics, 244, pp. 715-728.

Gillard, Q. (1981). The effect of environment amenities on house values: The example of a view lot. Professional Geographer, 33, pp. 216-220. 
Hang, M. (2019). How luxury developers use a loophole to build soaring towers for the ultrarich in N.Y. New York Times, April 20.

Hui, E.C.M., Zhong, J.W. \& Yu, K.H. (2012). The impact of landscape views and story levels on property prices. Landscape and Urban Planning, 105, pp. 86-93.

Hume, D. (1757). Of the standard of taste, London: Routledge and Sons, 1894, 36.

Jiao, L. \& Liu,Y. (2010). Geographic field model based hedonic valuation of urban open spaces, Landscape and Urban Planning, 98(1), pp. 47-55.

Jim, C.Y. \& Chen, W.Y. (2006). Impacts of urban environmental elements on residential housing prices in Guangzhou (China). Landscape and Urban Planning, 78, pp. 422-434.

Jim, C.Y. \& Chen, W.Y. (2007). Consumption preferences and environmental externalities: A hedonic analysis of the housing market in Guangzhou. Geoforum, 38, pp. 414-431.

Jim, C.Y., \& Chen, W.Y. (2009). Value of scenic views: Hedonic assessment of private housing in Hong Kong. Landscape and Urban Planning. 91(4), pp. 226-234.

Jim, C.Y. \& Chen, W.Y. (2010). External effects of neighborhood parks and landscape elements on high-rise residential value. Land Use Policy. 27(2), pp. 662-670.

Lake, I., Lovett, A., Bateman, I., \& Day, B. (2000). Using GIS and large-scale digital data to implement hedonic pricing studies. International Journal of Geographical Information Science. 14(6), pp. 521-541.

Li, M.M. \& Brown, H.J. (1980). Micro-neighborhood externalities and hedonic prices. Land Economics. 56(2), pp. 125-14.

Kahneman, D. (2011). Thinking fast and slow. London: Penguin.

Morancho, A.B. (2003). A hedonic valuation of urban green areas. Landscape and Urban Planning. 66, pp. 35-41.

Morton, T.G.(1977). Factor analysis, multicollinearity, and regression appraisal models. Appraisal Journal 45(4), pp. 578-588

Nicholls, S., \& Crompton, J. L. (2018). The contribution of scenic views of, and proximity to, lakes and reservoirs to property values. Lakes \& Reservoirs: Research \& Management, 23(1), 67-78.

Nicholls, S \& Crompton, J.L. (2017). The effects of rivers, streams and canals on property values. River Research and Applications. 33 (9), 1377-1386.

Paterson, R.W. \& Boyle, K.J (2002) Out of sight, out of mind? Use GIS to incorporate visibility in hedonic property value models. Land Economics, 72(3), pp. 417-425.

Pearson, L.J., Tisdell, C., \& Lisle, A.T. (2002). The impact of Noosa National Park on surrounding property values: An application of the hedonic price method. Economic Analysis \& Policy, 32(2), pp. 155-167. 
Peplow, M. (2014). Social sciences suffer from severe publication bias: Survey finds that 'null results' rarely see the light of the day. Nature, 28 August.

Rodriguez, M. \& Sirmans, C.F. (1994). Quantifying the value of a view in single-family housing markets. The Appraisal Journal, 62, pp. 600-603.

Sander, H.A. \& Polasky, S. (2009). The value of views and open space: Estimates from a hedonic pricing model for Ramsey County, Minnesota, USA. Land Use Policy, 26(3), pp. 837-845.

Scholey, J. M., \& Harrison, J. E. (2003). Publication bias: Raising awareness of a potential problem in dental research, British Dental Journal, 194, pp. 235-237.

Stozier, M. (2010). The cost of a view. New York Real Estate News. June 1.

Texas A\&M University and DePaul University (2011). Millennium Park quadruple net value report. College Station, Texas: Department of Landscape Architecture, Texas A\&M University.

Tse, R.Y.C. \& Love, P.E.D. (2000). Measuring residential property values in Hong Kong. Property Management, 18(5), pp. 366-374

Tyrväinen L. \& Miettinen, A. (2000). Property prices and urban forest amenities, Journal of Environmental Economics and Management, 39, pp. 205-223.

Ventiera, S. (20170 Rooms with a view. From Central Park to Golden Gate, price premiums on iconic vistas. The New York Times. May 1.

Walls, M., Kousky, C. \& Ziyan, C. (2015) Is what you see what you get? The value of natural landscape views. Land Economics, 91, pp. 1-19.

Webster, K. (2005). "View tax" triggers revolt in rural New Hampshire. Bangor Daily News, October 24.

Wilson, C. (2007) Paying up to see a long, long way. New York Times. March 14. 
Table 1

A Comparison of the Sale Price of Condominiums in the 400 ER Building which had Views of Millennium Park with those that did not have those Views

\begin{tabular}{|c|c|c|c|c|c|c|}
\hline & \multicolumn{2}{|c|}{$\begin{array}{c}\text { Millennium Park } \\
\text { View }\end{array}$} & \multicolumn{2}{c|}{ Other View } & \multicolumn{2}{l|}{} \\
\hline & Sales & $\$ /$ SF & Sales & \$SF & Difference/\$ & Difference/\% \\
\hline 2005 & 15 & $\$ 388.12$ & 26 & $\$ 310.84$ & $\$ 77.28$ & $24.9 \%$ \\
\hline 2006 & 11 & $\$ 419.71$ & 32 & $\$ 278.06$ & $\$ 141.64$ & $50.9 \%$ \\
\hline 2007 & 7 & $\$ 447.42$ & 27 & $\$ 307.07$ & $\$ 140.36$ & $45.7 \%$ \\
\hline 2008 & 5 & $\$ 448.43$ & 18 & $\$ 291.87$ & $\$ 156.56$ & $53.6 \%$ \\
\hline 2009 & 6 & $\$ 403.36$ & 17 & $\$ 280.34$ & $\$ 123.02$ & $43.9 \%$ \\
\hline 2010 & 5 & $\$ 390.19$ & 19 & $\$ 270.49$ & $\$ 119.69$ & $44.3 \%$ \\
\hline & $\mathbf{9 2}$ & & $\mathbf{2 9 1}$ & & $\$ 126.43$ & $\mathbf{4 3 . 9 \%}$ \\
\hline
\end{tabular}

Source: Texas A\&M University and DePaul University, 2011. 
Table 2

Summary of Findings Relating to the Impact of Views on Residential Property Values.

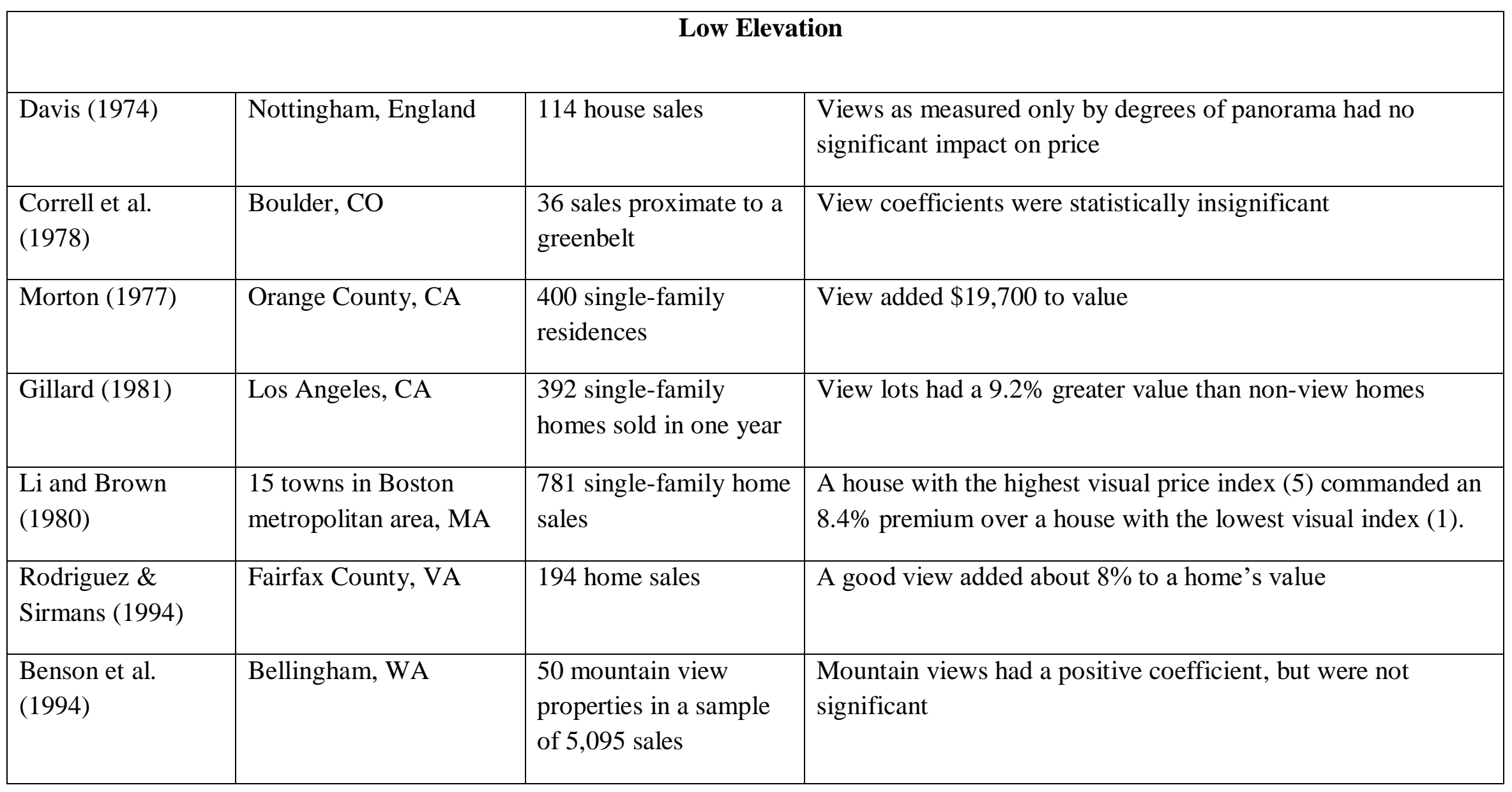




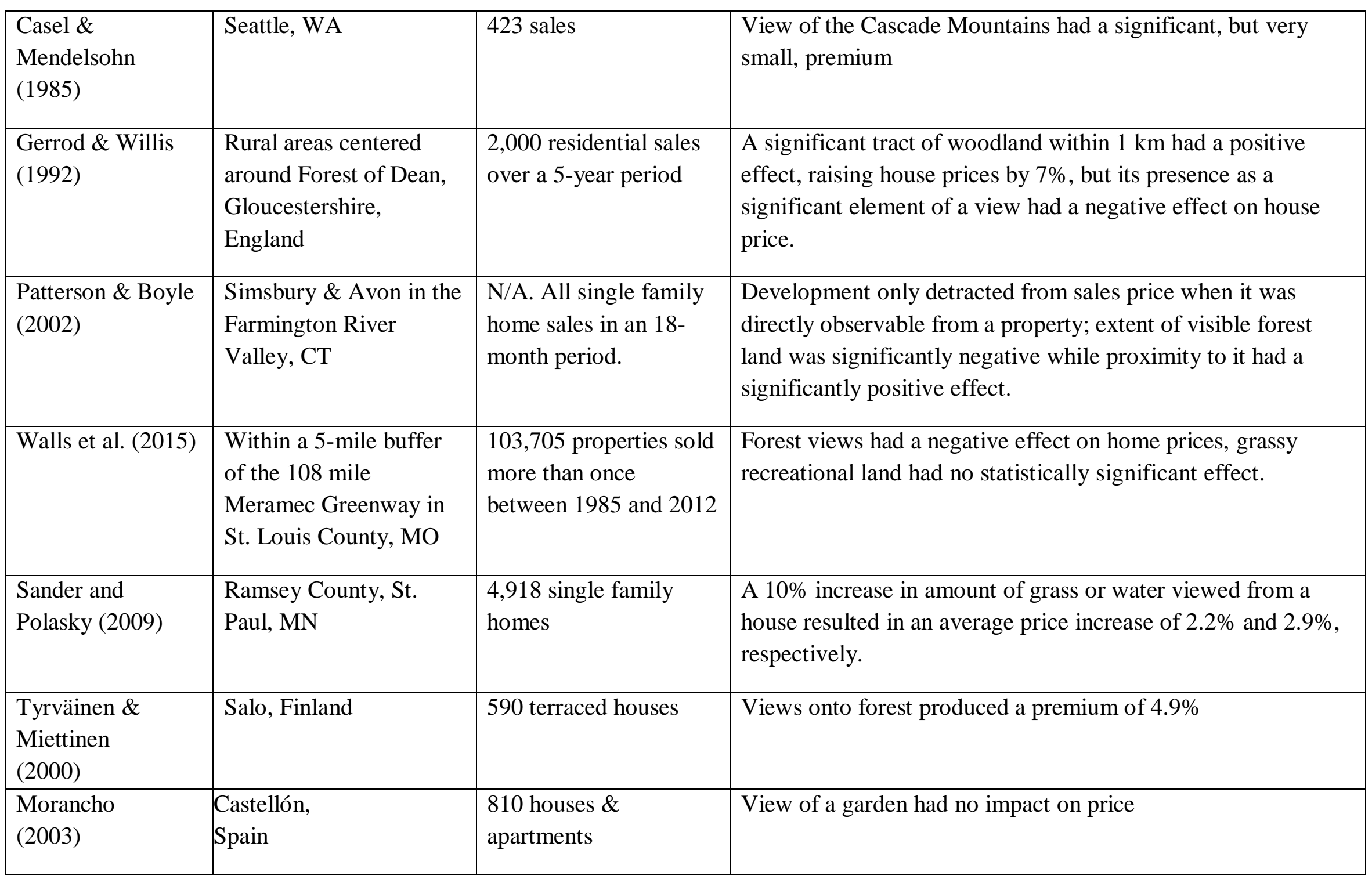




\begin{tabular}{|l|l|l|l|}
\hline Lake et al. (2000) & Glasgow, Scotland & $\begin{array}{l}3,456 \text { properties sold in } \\
1 \text { year }\end{array}$ & $\begin{array}{l}\text { Considered public parks as one of its land use categories. No } \\
\text { significant impact on house prices. }\end{array}$ \\
\hline $\begin{array}{l}\text { Cavallhás et al. } \\
(2008)\end{array}$ & $\begin{array}{l}\text { Suburban fringe of } \\
\text { Dijon, France }\end{array}$ & $\begin{array}{l}2,667 \text { sales of detached } \\
\text { houses over a seven } \\
\text { year period }\end{array}$ & $\begin{array}{l}\text { View has a greater influence on price than amount of land use } \\
\text { around a property; when in the line of sight, trees and farmland } \\
\text { commanded a positive premium; if out of sight, the effect was } \\
\text { insignificant; if a house was exposed to being viewed from } \\
\text { other houses, price was lowered. }\end{array}$ \\
\hline $\begin{array}{l}\text { Pearson et al. } \\
(2002)\end{array}$ & $\begin{array}{l}\text { Noosa National Park, } \\
\text { Queensland, Australia }\end{array}$ & $\begin{array}{l}641 \text { blocks of open } \\
\text { land }\end{array}$ & $\begin{array}{l}\text { Full panoramic and partial views of the park had a significant } \\
\text { positive impact on price }\end{array}$ \\
\hline
\end{tabular}

\begin{tabular}{|l|l|l|l|}
\hline \multicolumn{2}{|l|}{ High Elevations } \\
\hline $\begin{array}{l}\text { Baranzini \& } \\
\begin{array}{l}\text { Schaerer } \\
(2011)\end{array}\end{array}$ & $\begin{array}{l}\text { Geneva, } \\
\text { Switzerland }\end{array}$ & $\begin{array}{l}\text { Monthly rental } \\
\text { of 12,932 } \\
\text { apartments }\end{array}$ & $\begin{array}{l}\text { A view of urban parks (including sports fields) affected rent negatively, but } \\
\text { the area of them in the neighborhood was positive. View of natural } \\
\text { environments (trees and forests) had a greater impact on rent than its mere } \\
\text { presence in the neighborhood. }\end{array}$ \\
\hline $\begin{array}{l}\text { Tse \& Love } \\
(2000)\end{array}$ & Hong Kong & $\begin{array}{l}139 \text { apartments } \\
\text { from four } \\
\text { residential } \\
\text { estates }\end{array}$ & View of a cemetery had a negative premium of about 4\% \\
\hline $\begin{array}{l}\text { Chau \& Wong } \\
(2004)\end{array}$ & Hong Kong & $\begin{array}{l}859 \text { apartments } \\
\text { in a large estate }\end{array}$ & $\begin{array}{l}\text { View of internal gardens in a large estate yielded a 24\% higher price than } \\
\text { apartments with no view }\end{array}$ \\
\hline $\begin{array}{l}\text { Jim \& Chen } \\
(2009)\end{array}$ & Hong Kong & $\begin{array}{l}1,471 \text { apartment } \\
\text { sales from 18 }\end{array}$ & $\begin{array}{l}\text { Broad mountain views depressed prices by 6.7\%, while confined views were } \\
\text { statistically insignificant }\end{array}$ \\
\hline
\end{tabular}




\begin{tabular}{|l|l|l|l|}
\hline & & $\begin{array}{l}\text { residential } \\
\text { estates }\end{array}$ & \\
\hline $\begin{array}{l}\text { Jim \& Chen } \\
(2010)\end{array}$ & Hong Kong & 1,471 & $\begin{array}{l}\text { Neighborhood parks had a positive view premium of 1.95\%; a mountain view } \\
\text { decreased sales price by 2\% }\end{array}$ \\
\hline $\begin{array}{l}\text { Hui et al. } \\
(2012)\end{array}$ & Hong Kong & $\begin{array}{l}2,375 \text { sales of } \\
\text { condominiums }\end{array}$ & $\begin{array}{l}\text { Park views raised the price of a condominium by 5.94\% (c.f. to sea views } \\
\text { premium of 6.03\%) }\end{array}$ \\
\hline $\begin{array}{l}\text { Jim \& Chen } \\
\text { (2006) }\end{array}$ & Guangzhou, & 758 apartments & View accounted for 7.1\% of selling price \\
\hline $\begin{array}{l}\text { Jim \& Chen } \\
\text { China }\end{array}$ & $\begin{array}{l}\text { Guangzhou, } \\
\text { China }\end{array}$ & $\begin{array}{l}512 \text { apartment } \\
\text { sales from 312 } \\
\text { developments }\end{array}$ & $\begin{array}{l}\text { Greenview had a positive premium of 8.6\% on average; this increased to } \\
23.1 \% \text { in new town areas, but was insignificant in old town areas }\end{array}$ \\
\hline $\begin{array}{l}\text { Jiao \& Lui } \\
(2010)\end{array}$ & $\begin{array}{l}\text { Wuhan, } \\
\text { China }\end{array}$ & 304 apartments & $\begin{array}{l}\text { View of green spaces was not explicitly measured, but each higher floor } \\
\text { increased housing price by \$10 per square meter }\end{array}$ \\
\hline $\begin{array}{l}\text { Chen \& Jim } \\
(2010)\end{array}$ & $\begin{array}{l}\text { Shenzhan, } \\
\text { China }\end{array}$ & 358 apartments & $\begin{array}{l}\text { Premium for view of urban parks was 4.67\%; for residential gardens it was } \\
17.2 \%\end{array}$ \\
\hline
\end{tabular}


